\title{
New records of lignicolous fungi deteriorating wood in India
}

\section{Nagadesi $\mathrm{PK}^{1^{*}}$ and Arya $\mathrm{A}^{2}$}

\footnotetext{
${ }^{* 1}$ Department of Botany, Post Graduation Section, Andhra Loyola College, Vijayawada-520008, Andhra Pradesh, India. Email: nagadesipraveenkumar@yahoo.com.

${ }^{2}$ Department of Botany, Faculty of Science, The Maharaja Sayajirao University of Baroda, Vadodara - 390002, Gujarat, India. Email: aryaarunarya @ rediffmail.com
}

Nagadesi PK, Arya A 2012 - New records of lignicolous fungi deteriorating wood in India. Mycosphere 3(6), 997-1004, Doi 10.5943 /mycosphere/3/6/13

Wood deteriorating fungi were collected from Ratanmahal Wildlife Sanctuary (RWLS) between October 2006 and January 2011. Aurificaria indica var. leucocephala var. nov, and Microporus affinis var. glabriceps var. nov. are described and four species, Fomitopsis cupreorosea, Ganoderma curtisii, Microporus alboater and Phellinus shaferi are new reports for India. These six taxa are described and illustrated in this paper.

Key words - Aurificaria indica var. leucocephala - Gujarat - Microporus affinis var glabriceps Ratanmahal wildlife sanctuary - Wood decay fungi

\section{Article Information}

Received 1 November 2012

Accepted 7 November 2012

Published 31 December 2012

*Coresponding Author: Nagadesi Praveen Kumar - e-mail - nagadesipraveenkumar@yahoo.com

\section{Introduction}

The macrofungi have perhaps the longest history of diversity studies of any mycota. Nevertheless, they are understudied over most of the world. Taxonomic obstacles and the absence of long-term studies prevent conclusive answers even to basic questions about the number of species at a specific location or whether diversity is greater in one type of forest than in another (Lodge et al. 2004). It is known that the species of lignocellulolytic basidiomycetes are extremely abundant in all forest types and that they are the major wood decomposers in most ecosystems (Fryar et al. 1999). It is interesting to note that the history of study of Aphyllophorales is quite old in India. Bose (1919-1928) gave a comprehensive account on Indian Polypores collected from Bengal.
Sundararaman et al. (1924) reported several polypore from Madras. Sarbhoy et al. (19771981) listed more than 500 Aphyllophorales. Sarbhoy (1994) described the present status and future prospects of Mycology in India. Bakshi (1971) published a book on Indian Polyporaceae and Sharma (1995) on Hymenochaetaceae of India. Thind (1973) explored the mycoflora in Himalayas

Bakshi (1971) also reported Polyporus luteo-umbrinus Romell on ground attached to buried wood or root and dead fallen Heritiera minor in Baroda, Gujarat. Arya (2004) reported Ganoderma lucidum (Fr.) Ryv., Phellinus nilgheriensis (Mont.) Cunn., Trametes cingulata Fr., and T. Varians Van der Bij. from Baroda and Shoolpaneshwar wildlife sanctuary. Arya et al., (2008) reported that Lenzites sterioides is recorded for the first time 
on $T$. grandis. Two other basidiomycetous fungi $N$. floccosa and $C$. aspera are reported for the first time from India. We describe two new varieties and four new records to India (Bilgrami et al., 1979, Bilgrami et al., 1981, Jamaluddin et al., 2004, Thind and Dhanda 1980, Thind and Rattan 1971).

\section{Materials and Methods}

\section{Study area}

Ratanmahal Wildlife Sanctuary (RWS) is an area of approximately 55 sq. $\mathrm{km}$ consisting of dry deciduous forest. It lies between the Paanam and Orsang rivers in Limkheda taluka of Panchmahals district $\left(74^{\circ}\right.$ $37^{\prime}$ to $70^{\circ} 11^{\prime}$ East, $22^{\circ} 32^{\prime}$ to $22^{\circ} 35^{\prime}$ North). Ratanmahal forest contains 543 species of plants (119 trees, 40 shrubs, 238 herbs, 48 grasses, 87 climbers). Teak has the maximum density and comprises $19.6 \%$ of the total tree cover. Bhondaro (Lagerstroemia parviflora), constitutes $15.7 \%$ of the total composition.

\section{Material Collection}

Fungal specimens were collected in clean polythene bags from different locations and taken to the laboratory. Basidiomes were studied using macroscopic (eg. size, colour, number of pores $/ \mathrm{mm}$, length of tubes) and microscopic characters (presence/absence of structures, dimensions) (Ryvarden 1991). To observe basidia and setae, free-hand sections were made. For the clear observation of setae, trammel setae and setal hyphae, lactophenol cotton blue was used as staining and mounting medium. Xanthochoric reaction was also tested using potassium hydroxide solution. The various details of specimens were compared with Hymenochaetaceae of India (Sharma 1995), Indian Polyporaceae (Bakshi 1971), CBS Aphyllophorales database, New Zealand Fungi database, and Species Fungorum. Certain specimens were sent to the Forest Research Institute, Dehara Dun (India) for final confirmation. All fungi are kept in fungal collection of Botany Department of The M. S. University of Baroda, India.

\section{The Species}

Aurificaria indica (Massee) Reid var.
leucocephala var. nov.

Basidiocap annual, stiptiate, attached with 2-3 sporophores like a rosette, funnel shaped, thin leathery, pealing off cuticle present in mature sporophores, upper surface is yellow in fresh with black cuticle (Fig. 1a) in the center changed to brown cuticle covering in dry samples, fimbriate at zones, glabrous at margin, ornamented with crowded sulcate ridges, concentrically zoned with dark brown bands varying with golden brown zones. 15.3$18.6 \mathrm{~cm}$ long, $14-18 \mathrm{~cm}$ width, $0.5-1 \mathrm{~cm}$ thick, margin blunt, entire, wavy. Hymenium golden brown to blackish brown, pores visible to naked eye, angular, 2-4 per $\mathrm{mm}$, tubes separated (Fig. 1b), stalk is centrally present, concoloured, golden brown to dark brown, blunt, sulcate, 5-7.4 cm long, 2.5-7 cm width, 1-3 cm thick. context brown, black line present, consisting of only generative hypahae of large size, turning black in $\mathrm{KOH}$, hyphal system monomitic, generative hyphae thin to thick-walled, septate, branched, pale yellow to rusty brown, 6.3-2 $\mu \mathrm{m}$. Basidia pale yellow, clavate, thin walled $16.8 \times 3.12 \mu \mathrm{m}$. Basidiospores subglobose, hyaline, thinwalled, smooth, $6.1 \times 3.12 \mu \mathrm{m}$.

Habitat - On the ground attached to roots of Leucina leucocephala, Arboratum of Botany Department Baroda, (Gujarat), collected by N. Praveen Kumar, accession no: MSU Bot 80. 8-8-2008 - holotype.

Aurificaria indica var. indica differs from Aurificaria indica var. leucocephala by large centrally stiptiate rosette like cluster of pilei up to $20 \mathrm{~cm}$ diam. pealable, thin, brown cuticle, concentric zones of different coloures, sulcate ridges, pores $2-4$ per $\mathrm{mm}$, long stalk up to $8 \mathrm{~cm}$ in diameter, context with black line, fruiting body turning to black in $\mathrm{KOH}$, smaller spores. It is similar due to the presence of black cuticle in fresh samples and brown context, grayish brown pore layer, and monomitic hyphal system with thick-walled generative hyphae.

Ryvarden and Johansen (1980) reported $A$. indica on dead and living deciduous trees from Asia, Malaya and Africa (Kenya).

Fomitopsis cupreorosea (Berkeley) J. Carranza \& Gilbertson, Mycotaxon 25(2): 476, 1986, Polyporus cupreo-roseus Berk., Hook. 1856, J. Bot. 8. 

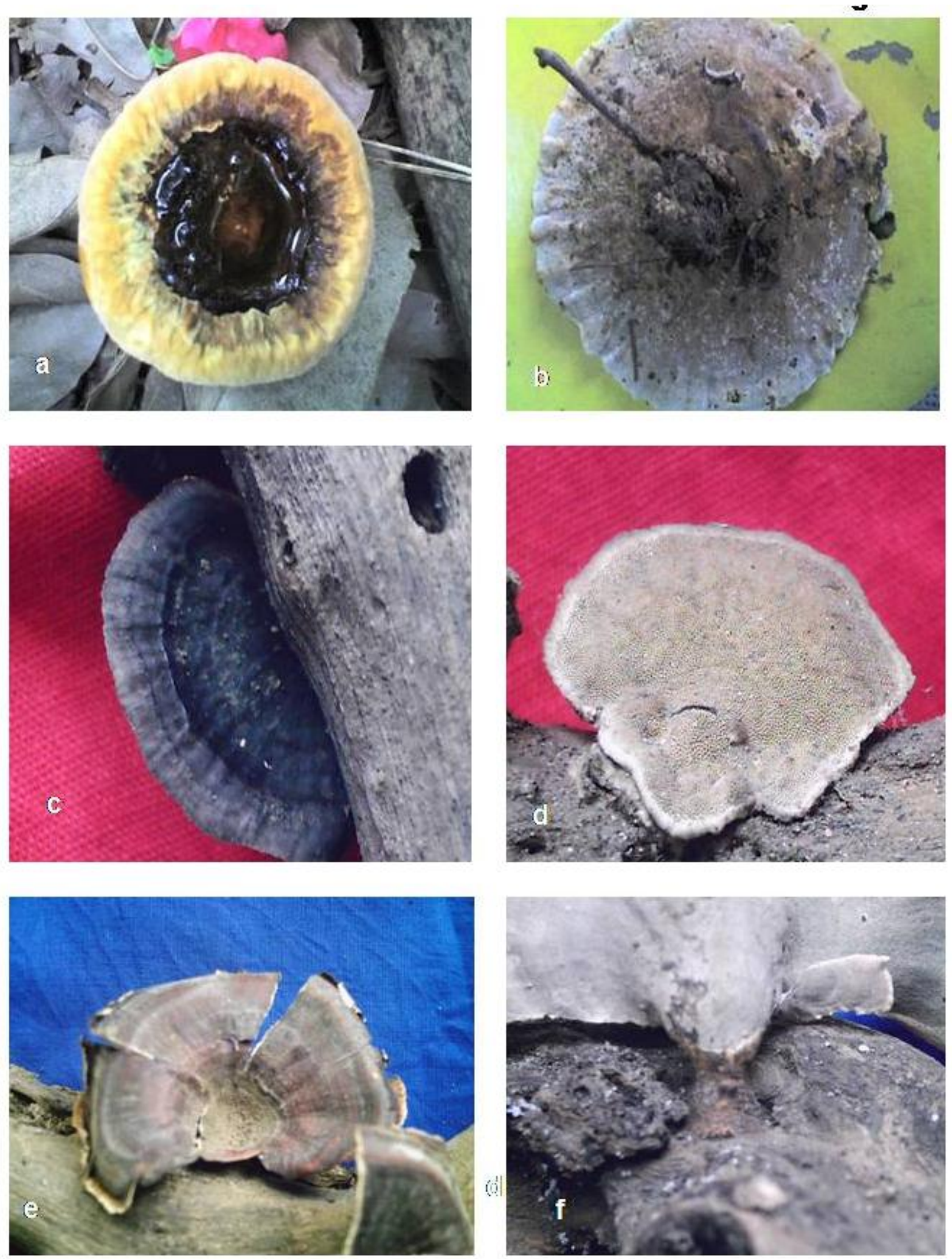

Fig. 1 - a Funnel shaped sporophore of Aurificaria indica var. lecuocephala, b Hymenium surface, c Fomitopsis cupreorosea attached to fallen branch of Terminalia arjuna showing the upper surface, d Pore surface, e Sporophore of Microporus affinis var. glabriceps, $\mathbf{f}$ Hymenium surface with stalk. 
Basidiocarp annual, solitary and imbricate, sessile or with a contracted base, dimidiate and broadly attached, with a resupinate hymenial surface frequently present (Fig. 1c), coriaceous to woody when dry; pileus aplanate, $5.0-9 \times 2.6-5.3 \times 0.3 \mathrm{~cm}$, resupinate part up to $0.8-1.5 \times 0.5 \mathrm{~cm}$; upper surface grayish brown, first velvety, fibrillose, becoming glabrous when old, with a weak silky dull shine, weakly sulcate, radiate-striate, strongly zonate in variable shades, old specimens dotted with protuberances or warts close to the base; margin sharp, acute, thin, entire; pore surface cinnamon brown (Fig. 1D), with a sterile margin up to $1.5 \mathrm{~mm}$; pores round, angular or subdaedaleoid, 1-3 per mm, dissepiments thick, entire; tubes concolorous with the pore surface, indistinctly stratified, up to $7 \mathrm{~mm}$ long, old tubes stuffed with white mycelium; context light brown, sometimes with a dark zone separating the tubes from context, dense, fibrous, up to $0.3 \mathrm{~cm}$ thick, with a black in $\mathrm{KOH}$. Hyphal system trimitic; generative hyphae with clamps, hyaline, thin to slightly thick-walled, occasionally branched, $3.15 \mu \mathrm{m}$ in diam; skeletal hyphae yellowish brown or hyaline, thick-walled, nonseptate, $6.13 \mu \mathrm{m}$ in diam; binding hyphae moderately branched, thick-walled 3.0-4.0 $\mu \mathrm{m}$ in diam. Cystidia or other sterile hymenial structures absent. Basidia clavate, 4-sterigmate, $19.0 \times$ $6.5 \mu \mathrm{m}$, with a basal clamp. Basidiospores cylindrical, hyaline, smooth-walled, 5.0-7.0 $\times$ 2.5-3.5 $\mu \mathrm{m}$, negative in Melzer's reagent.

Habitat - On fallen branches of Terminalia crinulata, Ratanmahal Wildlife Sanctuary, Gujarat, collected by N. Praveen Kumar, accession no: MSU Bot. 85; 7-122006. Rot: white fibrous rot.

Carranza-Morse et al. (1986) reported it on hard wood trees, very common on burned wood from Mexico, Central and South America; Caribbean Islands, causing brown cubical rot.

Microporus affinis var. glabriceps var. nov. (Blume \& T. Nees) Kuntze, Revis. gen. pl. (Leipzig) 3(2): 494; 1898

Sporophore annual, solitary, spathulate, short stipe, attached laterally, semicircular (Fig. 1e), dimidiate, flat and depressed in the area around the stipe. $2.7-5 \times$
1.4-3.3 $\times 0.3$, margin thin and usually flat. Pileus glabrous with slightly raised sulcate zone of dark brown crust of 20-40 $\mu \mathrm{m}$, upper surface reddish brown to almost black, tomentom absent Stipe lateral, $2.5 \mathrm{~cm}$ long 0.5 $\mathrm{cm}$ wide, velutinate throughout, round to slightly flattened, glabrous, blackish brown crust present(Fig. 1f). Hymenium grayish yellow, margin 1-3 mm wide and pure white, pores round and entire, very minute 7 per $\mathrm{mm}$, tubes light cream, up to $1 \mathrm{~mm}$ deep. context pure white and dense, up to $3 \mathrm{~mm}$ thick. Hyphal system trimitic and dextrinoid, generative hyphae hyaline and with clamps, 3 $\mu \mathrm{m}$ in diameter, skeletal hyphae in the context straight $9.4 \mu \mathrm{m}$ in diameter, thick-walled to almost solid, unbranched, aseptate, with wider lumen, binding hyphae common in the context and trama, much branched, mostly $3 \mu \mathrm{m}$ in diameter, with fewer side branches. Spores ellipsoid, hyaline and thin-walled, non-amyloid and $6.3 \times 2.5 \mu \mathrm{m}$

Habitat - On fallen branches of Terminalia crinulata, Ratanmahal Wildlife Sanctuary (Gujarat), collected by N. Praveen Kumar, accession no MSU Bot. 96, 7-2-20 (holotype).

Microporus affinis var. glabriceps resembles Microporus affinis but differs by absence of tomentose, black distinct crust over a white context, small sized sporophore, absence of black line, spores 4-5 x 2-2.5 $\mu \mathrm{m}$ and larger ellipsoidal spores size of $6.3 \times 2.5$ $\mu \mathrm{m}$. It resembles to $M$. xanthopus but it differs by having, stem is lateral and velutinate throughout, spores are slightly shorter, and hyphae are distinctly dextrinoid.

Ganoderma curtisii (Berk.) Murill, N. Am. Fl. 9: 120, 1908,

$\equiv$ Polyporus curtisii Berk., Hook. Journ. Bot. 1: 101, 1849.

Basidiocap annual, stipe lateral, aplanate, covered with cuticle, pileus rusty brown to grayish brown, golden brown zones (Fig. 2a), glabrous, undulate, usually slightly laccate, $10.8 \times 7.5 \times 0.6-1 \mathrm{~cm}$ thick, margin was blunt to entire, wavy, rusty brown. Hymenium rusty brown to grayish brown with yellow line of zone, $0.4 \mathrm{~cm}$ thick, pores circular (Fig. 2c), 3-5 per mm, tubes separate (Fig. 2b). Cuticle is very thin hymenioderm 

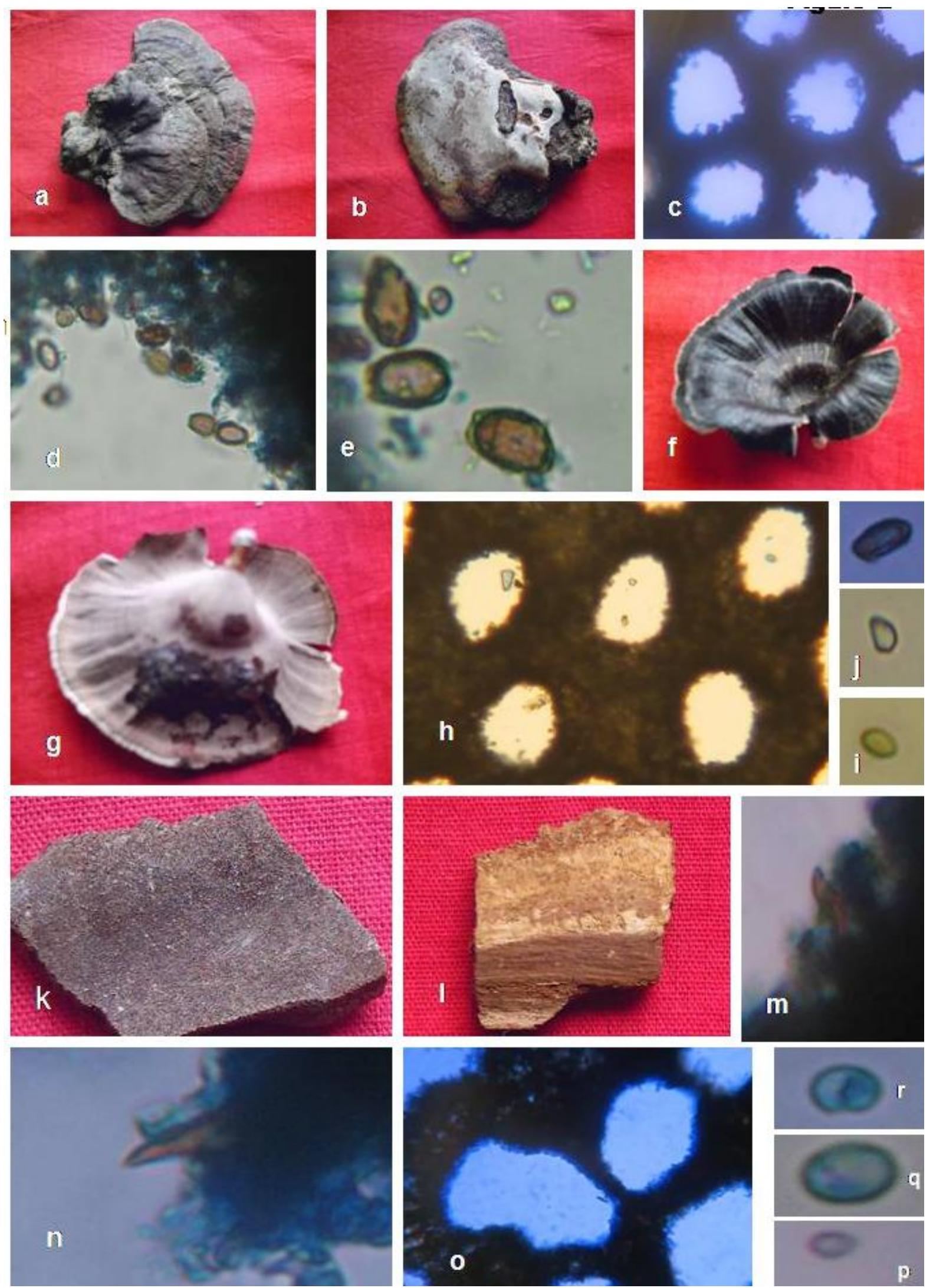

Fig. 2 - a Sporophore of Ganoderma curtisii showing upper surface b Lower surface, c Transverse section of pore layer, $\mathbf{d}$ Pore layer with basidiospores, $\mathbf{e}$ Truncate basidiospores, $\mathbf{f}$ Basidiocarp of Microporus alboater showing black upper surface, $\mathbf{g}$ hymenial surface, $\mathbf{h}$ Transverse section of tube layer, $\mathbf{i}-\mathbf{j}$ Basidospores, $\mathbf{k}$ Sporophore of Phellinus shaferi showing humenium layer, $\mathbf{l}$ Upper surface, $\mathbf{m}-\mathbf{n}$ Section showing setae, $\mathbf{o}$ Transverse section of tube layer $\mathbf{p}-\mathbf{r}$ Basidiospores 
type, usually not present cells upright and closely packed in grayish brown part of pileus, context brown, $0.3 \mathrm{~cm}$ thick, black line absent, Hyphal system dimitic, skeletal hyphae were thick-walled, rusty brown, septate, branched, clamped with narrow lumen, $5.9 \mu \mathrm{m}$. generative hyphae were pale yellow to brown, thin-walled, septate, clamped, branched, 3.12 $\mu \mathrm{m}$. cuticle was made up of golden yellow, thick-walled with $3.12 \mu \mathrm{m}$ diameter, bottle shaped, 25-46.8 $\times 9.3 \mu \mathrm{m}$. Basidia light yellow, clamped at base, clavate, $21.8 \times 3.12$ $\mu \mathrm{m}, 2$ sterigmata. Basidiospores brown, truncate, ellipsoidal to oveal, 8.5-11.4 × 5.7$6.2 \mu \mathrm{m}$ (Fig. 2d, e).

Habitat - At base of living tree Emblica officinalis, Ratanmahal Wildlife Sanctuary, (Gujarat), Accession no. MSU Bot. 84, 7-122006; on trunk of Peltophorum rouxbergii from sawmill of Station Road, Baroda, (Gujarat), collected by N. Praveen Kumar, Accession no: MSU Bot. 90. 4-4-2007.

Steyaert (1980) reported this species on dead wood, especially dead stumps in summer and autumn, from North California, USA.

Microporus alboater (Hennings) Kuntze, Revisio generum plantarum 3: 494, 1898.

$\equiv$ Polyporus alboater Hennings, Bot. Jahrb. Syst. 22: 92, 1895.

$\equiv$ Polyporus atrovillosus Ryv., Bull. Jard. Bot. Belg. 45: 200, 1975.

Basidiocarp annual, solitary or in small groups, centrally or rarely laterally stipitate, pileus infundibuliform, circular, even in laterally stipitate specimens where the lobes often meet around the point of attachment, leaving only a narrow opening from the stipe to the margin, pileus $4-7 \mathrm{~cm}$ in diameter, $1-2 \mathrm{~mm}$ thick, coriaceous and papery-thin along the margin, margin even and wavy. Pileus smooth, zonate with numerous concentric zones of reddish brown, upper surface deep brown to almost black (Fig. 2f), also with thin radiating lines, margin deflexed and usually lighter than the central areas, with a stereo-microscope $(30-40)$ it is possible to see numerous projecting, very short and dark skeletal hyphae from the cuticle but these are not visible to the naked eye, glabrous at maturity, nonxanthochoric. Stipe up to $4 \mathrm{~cm}$ long, light brown to more dirty brown with age, $2-3 \mathrm{~mm}$ in diameter, in young specimens hirsute and covered with grayish hairs, but with age these wear away from the upper part. Hymenium first light cream with a narrow white sterile margin (Fig. 2g), with age it darkens and is often discoloured with dark spots, pores very small and entire, 8 per mm, tubes very short, up to $1 \mathrm{~mm}$ (Fig. 2h). context pure white both in stipe and pileus, up to $1 \mathrm{~mm}$ thick at the centre. Hyphal system trimitic, skeletal hyphae were hyaline to pale yellow, septate, branched, thick-walled with wider lumen, 9.3 $\mu \mathrm{m}$, on the pileus projecting up to $120 \mu \mathrm{m}$ with darkened walls, in the lower part of the stipe, hyaline and up to $8 \mu \mathrm{m}$ in diameter with thickened walls. binding hyphae in the context, tortuous and much branched, apparently almost solid, $2-5 \mu \mathrm{m}$ in diameter generative hyphae were hyaline, aseptate, branched, thin walled, clamped, $3.12 \mu \mathrm{m}$. Basidiospores were dextrinoid, subglobose to ellipsoid, hyaline to pale yellow, thin-walled, $6.7 \times 3.1 \mu \mathrm{m}$ (Fig. $2 \mathrm{i}$, j.). $\begin{array}{lll}\text { Habitat }- \text { On fallen branches of } \\ \text { Terminalia arjuna and T. } & \text { crinulata, } \\ \text { Ratanmahal Wildlife Sanctuary } & \text { (Gujarat), }\end{array}$ collected by N. Praveen Kumar, accession No: MSU Bot. 80 and 81, 7-12-2006 and 30-12007. On fallen branches of $T$. bellerica from Shoolpaneshwar Wildlife Sanctuary, Didiapada (Gujarat), collected by Mr. J. Dinakaran, accession No: MSU Bot. 82, 23-9-2008. Rot: white fibrous rot.

Ryvarden \& Johansen (1980) reported this species on deciduous wood. It is a rare central African species and specimens were seen only from the Cameroons and Zaire and it may be that it is restricted to the central African rain forest but we found it in India.

Phellinus shaferi (Murrill) Ryvarden, Norweg. J. Bot. 19: 235, 1972.

$\equiv$ Fuscoporella shaferi Murrill, N. Amer. Flora 9(1): 7, 1907.

Basidiocarp perennial, resupinate, effused, attached to on upper surface facing hymenial layer, golden brown (Fig. 21), glabrous, $5 \times 2.8 \times 0.5 \mathrm{~cm}$ margin is thin uneven entire, Hymenium reddish brown with grayish tinch (Fig. 2k), pores angular to incised, $0.4 \mathrm{~cm}$ thick, 5-8 pores per $\mathrm{mm}$ (Fig. $20)$, tubes concolorous with pore surface, up to 
$2 \mathrm{~mm}$ deep Context is absent, if presen up to 1 mm thick, reddish-brown and fibrous, Hyphal system dimitic, skeletal hyphae golden brown, wider lumen, aseptate, unbranched, $3.12 \mu \mathrm{m}$ generative hyphae pale yellow thin-walled branched, septate, $2 \mu \mathrm{m}$ Basidia not found Basidiospores globose, pale yellow, thinwalled, 3.5-4.5 $\mu \mathrm{m}$ in diameter (Fig. 2p, q, r), Setae present dark brown, subventricose to acuminate with acute tip, straight $12-20 \times 4-8$ $\mu \mathrm{m}$ (Fig. 2m, n).

Habitat - On living tree of Aegle marmelos, Arboretum of Botany Department, The Maharaja Sayajirao University of Baroda, Gujarat, collected by Prof. Arun Arya, accession no. MSU Bot.100, 15-3-2007 Ryvarden \& Johansen (1980) reported this species from the type locality in Montserrat in the West Indies

\section{Acknowledgement}

The authors thank the Head, Department of Botany, The M S University of Baroda for laboratory facilities, and Dr. N.S.K Harsh, Forest Research Institute, Dehradun, India, for identifying the fungi. The study was funded by Department of Science and Technology, New Delhi.

\section{References}

Arya A, Albert S, Nagadesi P K. 2008 - New and interesting records of basidiomycetous fungi from Ratanmahal wildlife sanctuary, Gujarat. Journal of Mycolology \& Plant Pathology 38 (2), 221-226

Arya A. 2004 - New and interesting records of basidiomycetous fungi from Gujarat, India. In: Vistas in Palaeobotany and Plant Morphology: Evolutionary and Environmental Perspectives, Prof D D Pant Memorial Vol, PC. Srivastava (ed). UP Offset, Lucknow, India, pp 321-327.

Bakshi BK. 1971 - Indian Polyporaceae. Indian Council of Agricultural Research, New Delhi. 246 pp.

Bilgrami KS, Jamaluddin, Rizwi MA. 1979 Fungi of India part I. Today and Tomorrow's Printer and Publishers, New Delhi, 467 pp.
Bilgrami KS, Jamaluddin, Rizwi MA. 1981 Fungi of India part II. Today and tomorrow's printer and Publishers, New Delhi, 128 pp.

Bose SR. 1919-1928 - Polyporaceae of Bengal part I - IX Bull. Carmichael Medical College Belgachia; IV: 1-5

Carranza-Morse, J.; Gilbertson, R.L. 1986 Taxonomy of the Fomitopsis rosea complex (Aphyllophorales, Polyporaceae) Mycotaxon 25(2), 476

Fryar SC, Kirby GC, Hyde KD. 1999 - Species abundance patterns of two wood decay basidiomycete communities. Fungal Diversity 3, 39-56.

Jamaluddin, Goswami MG, Ojha BM. 2004 Fungi of India 1989-2001. Scientific Publisher, Jodhpur, India, $326 \mathrm{pp}$.

Lodge DJ, Ammirati JF, O'Dell TE, Mueller GM. 2004 - Collecting and describing macrofungi. In: Mueller GM, Bills GF, Foster MS. Biodiversity of fungi: inventory and monitoring methods. Elsevier Academic Press, Oxford, UK. $777 \mathrm{pp}$.

Ryvarden L, Johansen I. 1980 - A preliminary polypore flora of East Africa Oslo Norway, pp 434, 432, 110.

Ryvarden L. 1991 - Genera of PolyporesNomenclature and Taxonomy. Synopsis Fungorum 5 Fungal flora, OSLO, 363 pp.

Sarbhoy AK, Lal G, Varshney JL. 1984 Fungi of India (1977-1981) Associated Pub Company, New Delhi.

Sarbhoy AK. 1994 - Present status and future prospects of mycology in India. Indian Phytopathology 47(1), 1-18.

Sharma JR. 1995 - Hymenochaetaceae of India. Botanical Survey of India, Calcutta. $291 \mathrm{pp}$.

Steyaert RL. 1980 - Study of some Ganoderma species. Bull. Jard. Bot. Nat. Belgin 50, 135-186.

Sundararaman S, Marudarajan D. 1924 - Some Polyporaceae of the Madras presidency. Madras Agricultural Department. Year Book: 69-75.

Thind KS, Dhanda RS. 1980 - The Polyporaceae of India X. Kavaka 8, 5657.

Thind KS, Rattan SS. 1971 - The Polyporaceae 
Mycosphere Doi 10.5943/mycosphere/3/6/13

of India VIII, Research Bulletin Punjab University. (N.S.) 22, 27-34.

India, Presidential address delivered at the $25^{\text {th }}$ Annual General Body Meeting of Thind KS. 1973 - The Aphyllophorales in IPS 26(1), 2-23. 